\title{
PERUBAHAN SOSIAL PETANI PENERIMA PROGRAM BUMDES AGENG DI DESA NGROTO KECAMATAN PUJON KABUPATEN MALANG
}

\author{
Kiki Meylavinasari ${ }^{1}$, Agus Purnomo ${ }^{1 *}$, I Nyoman Ruja ${ }^{1}$ \\ ${ }^{1}$ niversitas Negeri Malang, Indonesia \\ *e-mail: agus.purnomo.fis@um.ac.id
}

\begin{abstract}
Abstrak
Tujuan penelitian ini adalah untuk menganalisis perubahan sosial pada petani penerima program BUMDes Ageng Desa Ngroto Kecamatan Pujon Kabupaten Malang. Penelitian ini menggunakan pendekatan kualitatif dengan jenis penelitian deskriptif. Sumber data yang digunakan adalah sumber data primer dan sumber data sekunder. Teknik pengumpulan data ada tiga, yaitu wawancara, observasi, dan dokumentasi. Simpulan penelitian ini adalah BUMDes memberikan perubahan pada kondisi sosial masyarakat Desa Ngroto khususnya para petani. Perubahan sosial mempengaruhi mata pencaharian, interaksi, pendapatan, pendidikan. Petani di Desa Ngroto memilih menggunakan pinjaman usaha bibit di BUMDes Ageng karena lebih menguntungkan bagi kondisi sosial petani.Program yang diberikan BUMDes Ageng juga berhasil mengentaskan sebagian Rumah Tangga Hampir Miskin di Desa Ngroto dari 477 KK menjadi $27 \mathrm{KK}$.
\end{abstract}

Kata kunci: BUMDes; Program BUMDes; Perubahan Sosial

\begin{abstract}
This study aimed to analyze the social change in farmers receiving the BUMDes Ageng program in Ngroto Village, Pujon District, Malang Regency. This study uses qualitative with descriptive research types. The data sources used are primary data sources and secondary data sources. There are three data collection techniques, namely interviews, observation, and documentation. The conclusion is that BUMDes changes to the social community of Ngroto Village specifically for farmers. Social change affects livelihoods, interactions, income, education. Farmers in Ngroto Village chose to use a seed business loan at BUMDes Ageng because it was more beneficial to social farmers. The program provided by BUMDes Ageng also succeeded in alleviating some of the Poorer Households in Ngroto Village from 477 households to 27 households. Ngroto Village is also the best village in Indonesia with the Highest Building Village Index.
\end{abstract}

Keywords: BUMDes; Program of BUMDes; Social Change

\section{PENDAHULUAN}

Setiap daerah memiliki program Badan Usaha Milik Desa yang bertujuan untuk meningkatkan kesejahteraan masyarakat. Badan Usaha Milik Desa (BUMDes) merupakan badan usaha yang seluruh atau sebagian besar modalnya dimiliki desa, melalui penyertaan modal langsung yang berasal dari kekayaan desa. Menurut pasal 1 ayat 6 UU Desa tahun 2014 menjelaskan 
BUMDes merupakan badan usaha yang seluruh atau sebagian besar modalnya dimiliki oleh desa melalui penyertaan secara langsung yang berasal dari kekayaan desa yang dipisahkan guna mengelola aset, jasa pelayanan, dan usaha lainnya untuk sebesarbesarnya kesejahteraan masyarakat desa.

Sebagai salah satu lembaga ekonomi yang beroperasi di perdesaan, BUMDes harus memiliki perbedaan dengan lembaga ekonomi pada umumnya. Lembaga ini sebagai kekuatan yang dapat mendorong terciptanya peningkatan kesejahteraan dengan cara menciptakan produktivitas ekonomi bagi desa dengan berdasar pada ragam potensi yang dimiliki desa. Lembaga ini harus muncul atas kehendak seluruh warga desa yang diputuskan melalui musyawarah desa. Musyawarah desa merupakan suatu forum tertinggi melahirkan berbagai keputusan utamanya.

BUMDes didirikan oleh pemerintah desa yang kepemilikan modal dan pengelolaannya dilakukan oleh pemerintah desa dan masyarakat. keberadaannya sangat berpengaruh terhadap pembangunan ekonomi masyarakat. Pembangunan ekonomi bertujuan dalam membangun daerah perdesaan yang memiliki kualitas sumber daya manusia yang lebih baik untuk meningkatkan produktivitas dan keanekaragaman usaha perdesaan. Oleh karena itu pembentukannya memiliki harapan supaya mampu memberikan perubahan dalam hal sosial terhadap masyarakat.

Pendirian BUMDes sesuai dengan kebutuhan, kondisi ekonomi, dan sosial budaya masyarakat. Salah satu hal penting yang harus menjadi pertimbangan mendirikannya, bahwa jenis usaha yang dipilih harus mampu menampung, dan mewadahi kegiatan usaha ekonomi desa (Apriyani, 2016). Keberhasilan BUMDes diukur dari perubahan pendapatan masyarakat. Salah satunya yang terdapat di Desa Ngroto.

Desa Ngroto
Kabupaten
Malang memiliki program

BUMDes yang mampu memberikan perubahan sosial terhadap masyarakat yang bekerja sebagai petani. Lembaga ini diresmikan pada tanggal 15 Desember 2015 dengan nama BUMDes Ageng. Sebelum memberikan bantuan pinjaman sementara, perangkat desa beserta pengurus BUMDes melakukan pemetaan untuk masyarakat yang tergolong miskin di wilayah Desa Ngroto dengan tujuan untuk memberikan bantuan pinjaman sementara kepada masyarakat yang benar-benar dinyatakan masih kurang mampu tetapi memiliki usaha atau pekerjaan. Keberhasilannya sudah terlihat sejak awal tahun 2018 yang saat ini sudah berhasil mengentaskan sebagian besar rakyat miskin di Desa Ngroto. Beberapa daerah melakukan kunjungan untuk mencari wawasan ataupun melakukan studi banding seperti kunjungan dari Kalimantan dan Papua.

BUMDes Ageng memiliki strategi dan peran yang cukup bagus dalam mengentaskan sebagian masyarakat miskin di Desa Ngroto termasuk petani. Terdapat beberapa program simpan pinjam untuk masyarakat miskin. Pada sektor pertanian memberikan pinjaman berupa Pinjaman Usaha Bibit (PUB) dengan pinjaman ini petani khususnya petani bibit dapat membeli bibit yang dapat dibayar dengan batas waktu satu bulan. Bibit pertanian yang dijual kepada petani memiliki harga yang cukup terjangkau dan lebih murah dibanding bibit yang dibeli di toko pertanian biasa, maka petani tersebut memperoleh keuntungan yang cukup besar (Hadi, 2018).

Selain diberi pinjaman sementara para petani juga diberikan penyuluhan serta pelatihan terhadap penanaman maupun produksi pertanian yang baik. Pinjaman sementara dan penyuluhan produksi pertanian memberikan pengaruh yang cukup besar terhadap perubahan sosial petani di Desa Ngroto, dapat dilihat dari interaksi yang terjalin sangat baik antar petani ketika bertukar informasi tentang masalah pertanian ataupun berbagi ilmu dalam hal penanaman maupun produksi pertanian, kemudian 
karena kualitas dan hasil panen pertanian yang lebih banyak dari sebelumnya juga meningkatkan pendapatan petani. Dengan diberikan penyuluhan serta kegiatan sosialisasi kepada petani menimbulkan perubahan aktivitas produksi pertanian. Perubahan aktivitas produksi pertanian merupakan perubahan-perubahan yang timbul dari adanya pengelolaan pertanian yang baik dari petani yang mempengaruhi kualitas hasil produksi.

\section{METODE}

Fokus penelitian ini adalah Perubahan Sosial pada Petani Penerima Program BUMDes Ageng di Desa Ngroto Kecamatan Pujon Kabupaten Malang. Maka untuk memperoleh dan mengumpulkan data, peneliti mengkaji penelitian ini menggunakan pendekatan kualitatif dengan jenis penelitian deskriptif. Lokasi penelitian ini bertempat di Desa Ngroto, Kecamatan Pujon, Kabupaten Malang. Data penelitian ini didapatkan melalui sumber primer dan sumber sekunder. Data primer adalah data yang diperoleh langsung di lokasi penelitian, melalui pengamatan langsung di lapangan dan melalui proses wawancara dengan informan. Sedangkan data sekunder adalah data yang diperoleh dari studi literatur. Berkaitan dengan sumber data yang akan digunakan dalam penelitian ini, sumber data dapat berupa manusia sebagai informan, hasil wawancara, atau sumber tertulis yang mendukung untuk dijadikan data dalam penelitian ini seperti artikel, majalah, berita, ataupun koran. Informan pendukung dalam penelitian ini adalah Kepala Desa Ngroto, Kepala Pengurus BUMDes Ageng dan Sekertaris BUMDes. Informan pendukung berperan sebagai informan yang dapat memberikan arahan untuk menemukan informasi kunci. Setelah mendapatkan data dari informan pendukung, peneliti melakukan wawancara kepada informan kunci guna melengkapi dan mencari jawaban atas topik pembahasan penelitian. Informan kunci dari penelitian ini adalah beberapa petani bibit yang melakukan pinjaman usaha bibit di
BUMDes Ageng. Alasan peneliti memilih informan kunci didasarkan pada fokus penelitian yaitu subjek peneliti yang berfokus pada BUMDes Ageng di Desa Ngroto.

Teknik pengumpulan data dalam penelitian ada tiga, yaitu wawancara, observasi, dan dokumentasi. Aktivitas menganalisis data menggunakan analisis data menurut (Miles \& Huberman, 2014) yaitu pengumpulan data, reduksi data, penyajian data, dan kesimpulan atau verifikasi. Tahaptahap penelitian yang dilakukan ada 3, tahap pra lapangan, pekerjaan lapangan, dan pelaporan. Tahap pra lapangan dilakukan sebelum peneliti melakukan penelitian di lapangan, diantaranya, menyusun rancangan penelitian, melakukan observasi awal, mempelajari buku atau jurnal yang berhubungan fokus penelitian, menyusun proposal proposal serta instrumen penelitian, melakukan seminar proposal dan mengurus surat izin penelitian. Kemudian tahap pekerjaan lapangan dilakukan peneliti dengan mengumpulkan data melalui observasi, wawancara, dan dokumentasi. Selanjutnya tahap terakhir adalah pelaporan, tahapan penelitian ini dilakukan setelah data yang dikumpulkan disesuaikan dengan fokus penelitian yang telah ditentukan.

\section{HASIL DAN PEMBAHASAN \\ Profil BUMDes Ageng}

Pemerintah Desa Ngroto membentuk Badan Usaha Milik Desa untuk menindak lanjuti visi dan misi Desa Ngroto. Hal tersebut ditujukan untuk pemberdayaan masyarakat Desa Ngroto yang terbilang waktu itu masih kurang. BUMDes dibentuk sebagai implementasi amanat Undang-undang Nomor 6 tahun 2014 tentang desa maka Pemerintah Desa Ngroto, Badan Permusyawaratan Desa, Lembaga Pemberdayaan Masyarakat Desa membentuk POKJA Pendirian Badan Usaha Milik Desa Ngroto.

Pada 2015 BUMDes Ageng diresmikan di Desa Ngroto setelah berhasil mematangkan regulasi serta aturan yang ada, prosesnya dibentuk bersama 
pemerintah kecamatan, kabupaten dan akademisi. Setelah itu terbit undang-undang peraturan desa melalui musyawarah desa. Pemilihan nama BUMDes Ageng sendiri juga memiliki makna yang berkaitan dengan Desa Ngroto. Melalui musyawarah bersama pemerintah desa, BPD, LPMD, PKK dan tokoh- tokoh masyarakat terpilihlah nama Ageng. Nama Ageng adalah sebuah tujuan dan doa, agar lembaga ini dapat berjalan dengan baik dan lancar serta menjadi besar yang mampu menjadi penopang perekonomian di Desa Ngroto. Sedangkan masyarakat Desa Ngroto menganggap Ageng sendiri memiliki arti yaitu besar serta Ageng adalah nama orang yang pertama kali ada di Desa Ngroto yaitu Ageng Ronggo Pramono. Perhatikan Gambar 1 untuk lebih mudahnya untuk memahami proses pembentukan BUMDes.

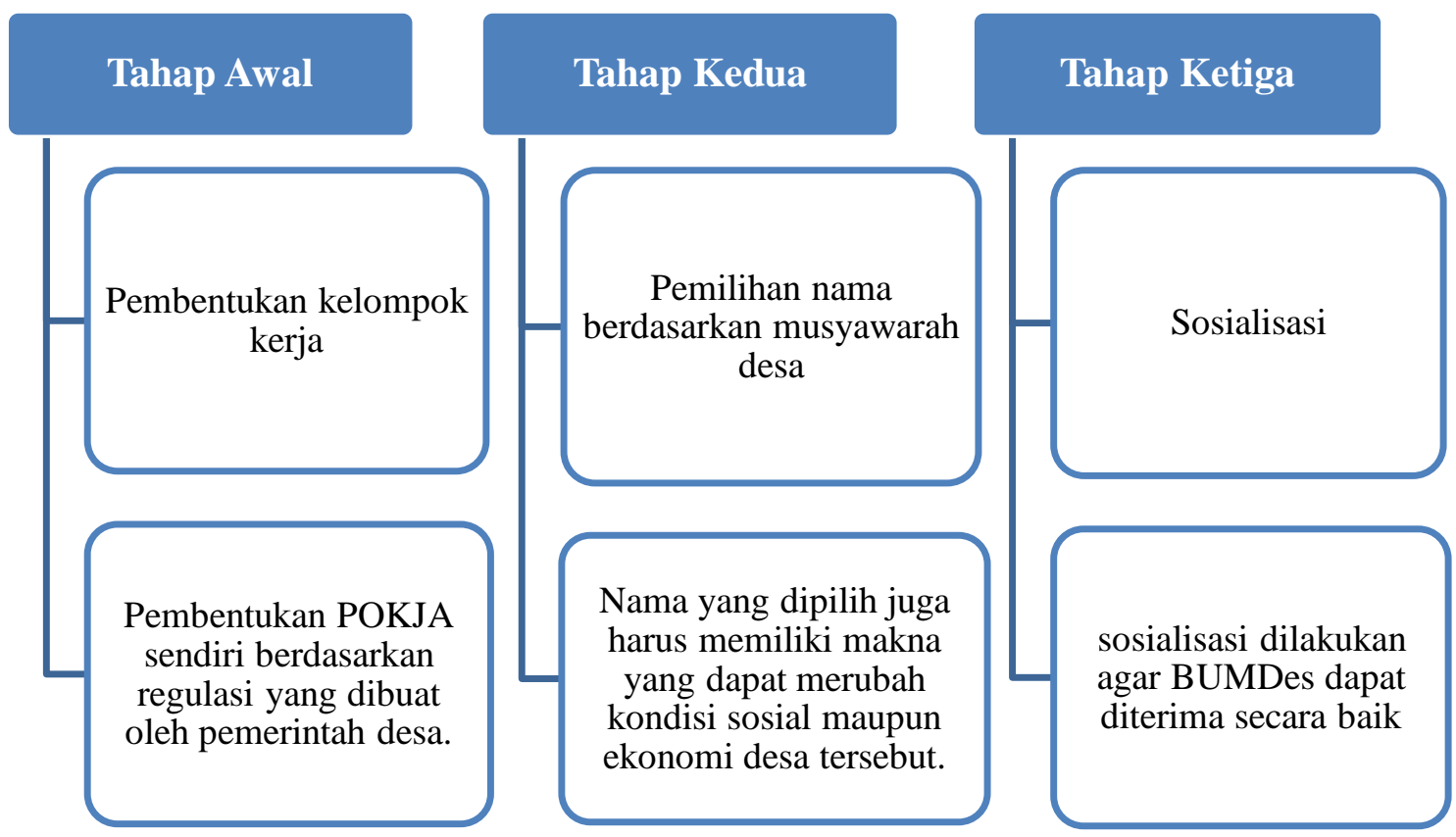

Gambar 1. Tahapan Berdirinya BUMDes

Kelompok kerja BUMDes Ageng berasal dari perangkat Desa Ngroto. POKJA dibentuk bersamaan dengan sosialisasi BUMDes. Berikut gambar 1 adalah susunan kelompok kerja di BUMDes Ageng yang telah dibuat oleh Kepala Desa Ngroto. Pembentukan POKJA sebenarnya menurut regulasi yang ada tidak bisa diberikan kepada perangkat desa yang sudah bertugas di kantor kepala desa. Tetapi karena adanya kebijakan dari pemerintah maka perangkat desa dapat diangkat sebagai pengurus
BUMDes Ageng yang bertujuan juga untuk mendampingi kinerja BUMDes di Desa Ngroto. Tahapan sosialisasi dilakukan pada setiap RT yang ada di Desa Ngroto. Sedangkan ketentuan berdirinya BUMDes, terkait penyertaan modal, dan pembentukan POKJA tercantum dalam Perdes yang telah dibuat. 


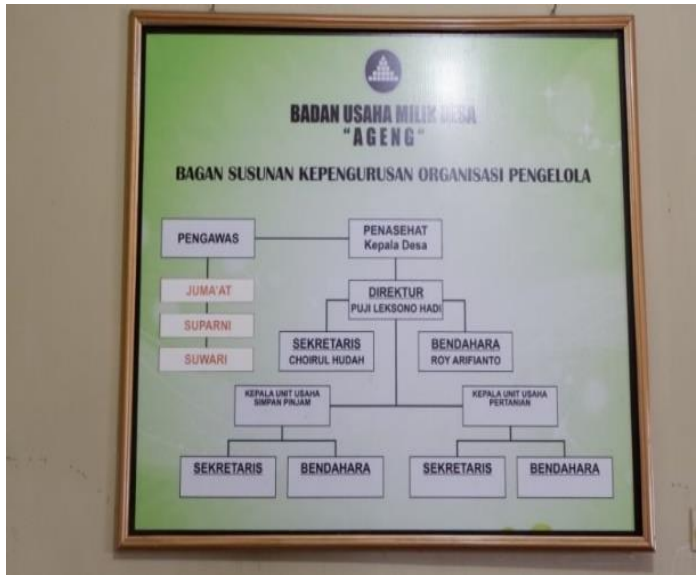

Gambar 1 Bagan pengurus BUMDes Ageng

Tujuan berdirinya BUMDes Ageng adalah meningkatkan perekonomian di Desa Ngroto serta menciptakan perubahan sosial yang lebih baik bagi masyarakat Desa Ngroto. Hal tersebut sejalan dengan visi BUMDes Ageng yaitu menuju masyarakat yang mandiri dan sejahtera. Sedangkan misi BUMDes Ageng sendiri yaitu, 1) menggali potensi ekonomi desa, 2) meningkatkan peran UKM dan usaha kecil lainnya untuk memperbesar kesempatan kerja dan berusaha, 3) menciptakan akses permodalan yang mudah dan murah, 4) membangkitkan kegiatan ekonomi kecil dan menengah yang berdaya saing, 5) menumbuh kembangkan usaha-usaha ekonomi di segala sektor, 6) menciptakan produk unggulan ekonomi desa sesuai dengan karateristik desa, 7) menciptakan masyarakat desa yang sejahtera dan mandiri. Visi dan misi tersebut tercantum dalam dokumen BUMDes Ageng Desa Ngroto.

Pada 2017 BUMDes Ageng mulai mematangkan perannya terhadap perekonomian Desa Ngroto. Dana bantuan dari pemerintah diberikan terhadap Desa Ngroto untuk diberikan kepada masyarakat Desa Ngroto yang memiliki usaha kecil dan simpan pinjam. Dana tersebut sebagian dikelola oleh BUMDes Ageng dan digunakan sebagai penyertaan modal bagi desa yang ditujukan untuk masyarakat Desa Ngroto.
Kemudian di tahun 2018 perkembangan akan kinerja BUMDes mulai terlihat baik karena semakin berkurangnya masyarakat miskin di Desa Ngroto.

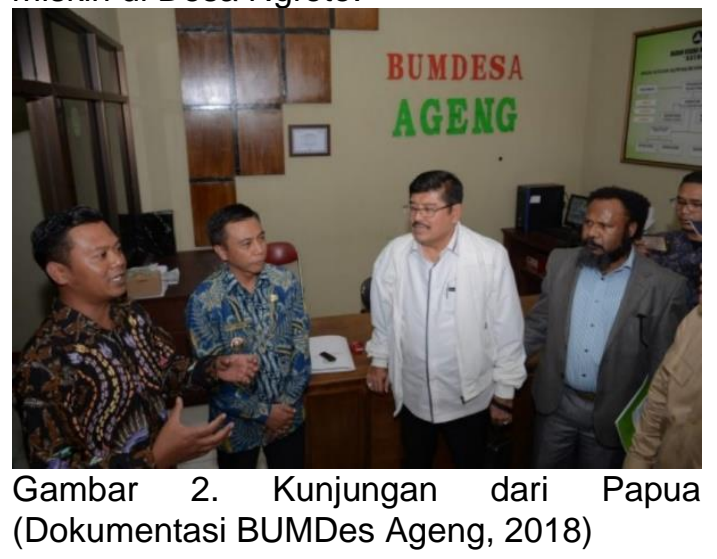

BUMDes Ageng juga mendatangkan kunjungan dari luar termasuk kegiatan Study banding (gambar 2) dari BUMDes luar daerah lainnya yang masih dalam tahap awal. Tujuannya sendiri adalah untuk mendapatkan wawasan baru dari BUMDes Ageng yang sudah berjalan baik.

\section{Perubahan Sosial Petani Penerima Program BUMDes}

BUMDes merupakan lembaga yang dibentuk oleh pemerintah desa sebagai upaya memperbaiki kondisi sosial masyarakat desa yang memiliki potensi cukup baik . Desa Ngroto juga menjadi desa terbaik se Indonesia karena IDMnya tinggi dan mengalami perubahan yang sangat signifikan. Hal tersebut karena adanya peran pemerintahan desa bersama BUMDes Ageng untuk mendorong masyarakat menjadi lebih peduli pada kondisi sosial mereka, dan masyarakat memiliki kesadaran yang tinggi terhadap kemajuan desa.

Pemerintah memfasilitasi dalam bentuk pelatihan dan pendidikan yang dapat memperlancar kegiatan BUMDes Ageng. Peran kelembagaan bagi desa sangat penting dalam mengatur sumberdaya dan distribusi manfaat dari adanya potensi di suatu wilayah (Tama \& Ovi, 2017). Program 
BUMDes yang ditetapkan oleh pemerintah desa adalah Program Jalin Matra, program pinjaman usaha kecil, tabungan umum, pinjaman usaha bibit (gambar 3), tabungan hari raya, arisan sembako, deposito. Pinjaman Usaha Bibit (PUB) terfokus pada petani yang sesuai dengan potensi wilayah. Untuk menentukan unit usaha dan rancangan alternatif klarifikasi jenis usaha juga dirumuskan bersama masyarakat desa yang sesuai dengan potensi wilayah dan usaha masyarakat terdahulu (Putra, 2015).

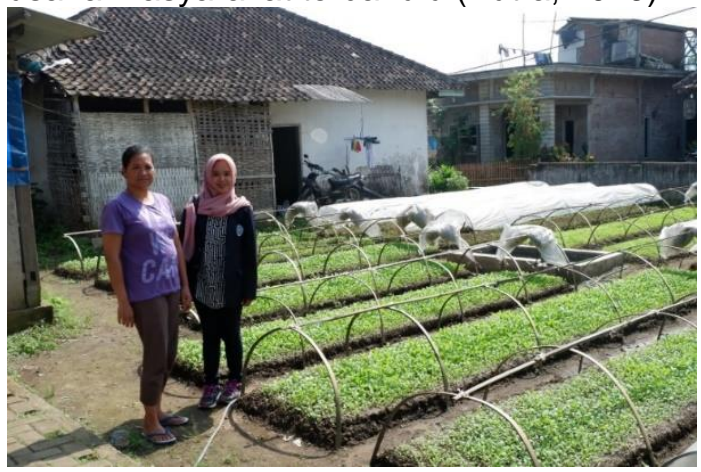

Gambar 3. Petani kebun bibit mitra BUMDes Ageng

BUMDes berperan penting dalam perbaikan kondisi sosial masyarakat. Desa yang memiliki potensi SDA dapat membantu peningkatan kondisi sosial dengan diiringi program BUMDes. Program atau unit usaha yang dibuat oleh BUMDes harus sesuai dengan potensi yang ada hal tersebut untuk mengembangkan usaha yang telah ada dan tidak mematikan usaha yang telah didirikan oleh masyarakat (Bambang, 2017).

Peran BUMDes memberikan keuntungan terhadap masyarakat desa khususnya petani para penerima program BUMDes. Pendapatan asli desa juga mengalami kenaikan karena kinerja BUMDes yang baik dalam programnya mengatasi Rumah Tangga Hampir Miskin. BUMDes juga memberikan bunga yang relatif rendah dibanding dengan jasa peminjaman di luar desa. BUMDes pada dasarnya memang ditujukan untuk masyarakat desa sebagai pendongkrak ekonomi dan pengembangan sumberdaya (Maryuarni, 2008).

Petani memilih melakukan pinjaman di BUMDes sebagai bentuk pemanfaatan sumberdaya yang telah disediakan oleh pemerintah desa. Tujuan petani menggunakan program BUMDes sebagai pengurangan peminjaman dari luar desa seperti rentener (pinjaman dari pihak swasta dengan bunga tinggi) dan mengedepankan badan usaha yang telah ada. Teori rasional Coleman menyatakan bahwa tindakan perseorangan mengarah pada suatu tujuan (Wirawan, 2015).Petani yang beralih menggunakan pinjaman BUMDes semakin berubah kondisi sosialnya (lihat gambar 4, formulir pinjaman). Perubahan sosial terjadi pada waktu yang berbeda, antara keadaan sistem tertentu dalam jangka waktu berlainan (Martono, 2014).

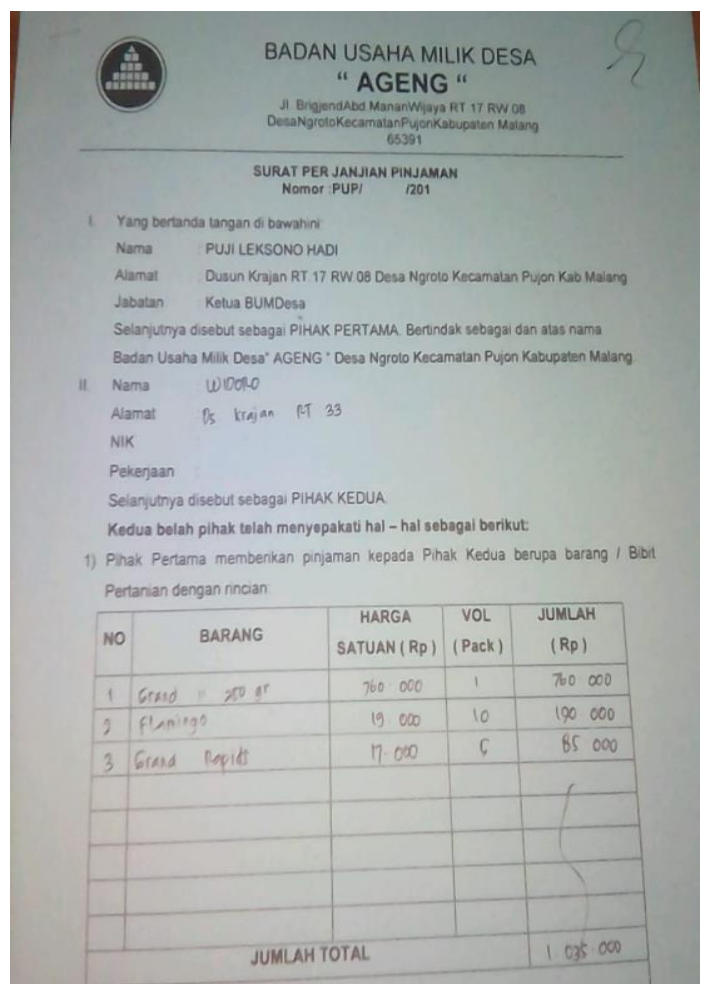

Gambar 4. Form pengajuan pinjaman petani mitra ke BUMDes Ageng 
Perubahan sosial yang terjadi pada
petani mencakup perubahan mata
pencaharian, pendapatan, pendidikan, dan
interaksi. Peran BUMDes memberikan
dampak positif bagi peningkatan pendapatan
masyarakat khususnya masyarakat pengguna dana simpan pinjam BUMDes (Nur, 2017). Pendapatan petani yang meningkat dapat memberikan dampak bagi pendapatan asli desa. Menurut Permendagri No. 113 tahun 2014 menyatakan Pendapatan asli desa adalah semua penerimaan uang melalui rekening desa yang merupakan hak desa dalam satu tahun anggaran yang tidak perlu dibayar kembali oleh desa. Pendapatan desa dapat berasal dari hasil usaha yaitu hasil BUMDes yang masyarakat juga ikut serta dalam kerja sama BUMDes.

Pendapatan petani yang meningkat dapat mengubah kondisi sosial dan merubah pola pikir untuk lebih mementingkan pendidikan sebagai bekal masa depan. Pendidikan memiliki peran yang sangat penting bagi peningkatan kualitas sumberdaya manusia (Krismiyati, 2017). Interaksi petani dengan BUMDes dan antar petani terjalin baik karena keduanya saling membutuhkan. Interaksi merupakan relasi antara dua sistem yang terjadi sedemikian rupa sehingga kejadian yang berlangsung akan mempengaruhi kejadian pada sistem lainnya (Fatna \& Anam, 2014). Hal tersebut menguntungkan bagi BUMDes karena masyarakat penerima program BUMDes dapat menaati regulasi dengan baik.

\section{SIMPULAN DAN SARAN}

Perubahan sosial yang terjadi pada petani bibit di Desa Ngroto berupa pendapatan, pendidikan, dan interaksi. Pendapatan petani bibit Desa Ngroto mempengaruhi pendapatan asli desa. Peningkatan pendapatan petani menyebabkan kesadaran akan pentingnya pendidikan bagi anak mereka untuk menunjang perekonomian keluarga. Interaksi yang terjadi dengan BUMDes Ageng cukup baik. BUMDes Ageng telah memberikan pinjaman dan hal tersebut sangat memudahkan bagi petani bibit sebagai modal awal mereka. Tetapi juga terjadi interaksi yang kurang baik antar petani ketika gagal panen persaingan semakin tinggi. BUMDes Ageng dinilai telah memberikan peran yang sangat baik bagi petani bibit dengan program usaha bibit yang telah ada dan dapat mengentaskan sebagian masyarakat miskin di Desa Ngroto.

BUMDes Ageng didirikan untuk memperbaiki kondisi ekonomi masyarakat Desa Ngroto khususnya petani dan telah berhasil memberikan perubahan sosial bagi masyarakat Desa Ngroto. Jadi, pemerintah dan masyarakat harus tetap mendukung adanya program BUMDes Ageng. Pemerintah harus mendampingi kegiatan BUMDes agar berjalan dengan baik dan program-program BUMDes dapat dibagikan secara merata. Masyarakat juga harus tertib dalam kegiatan simpan pinjam agar BUMDes tetap berjalan dengan lancar.

\section{DAFTAR PUSTAKA}

Apriyani, S. A. (2016). Strategi Badan Usaha Milik Desa Tirta Mandiri dalam Pengelolaan Objek Wisata Umbul Ponggok di Kecamatan Polanharjo Kabupaten Klaten. 1-11.

Bambang. (2017). Pemetaan Arah Kebijakan Pengembangan Badan Usaha Milik Desa di Kecamatan Kaligondang Kabupaten Purbalingga.

Fatna, V. N., \& Anam, C. (2014). Kemampuan Interaksi Sosial Antara Remaja Yang Tinggal di Pondok Pesantren.

Ghony, M. D., \& Almanshur, F. (2012). Metodologi Penelitian Kualitatif. Yogyakarta: Ar-ruzz Media.

Hadi, P. L. (2018, Oktober 20). Peran BUMDes Ageng terhadap Perubahan Sosial Petani . (K. Meylavinasari, Interviewer)

Krismiyati. (2017). Pengembangan Sumber Daya Manusia dalam Meningkatkan

Jurnal IImu Sosial dan Humaniora | 228 
Kualitas Pendidikan di SD Negeri Inpres Angkasa Biak.

Kurniawan, Y. T. (2018). Strategi Optimalisasi Program

Penanggulangan Kerentanan Kemiskinan (Studi Kasus Jalinmatra PK2 di Desa Ngroto Kecamatan Pujon Kabupaten Malang).

Lutfiyatunnada, R. (2018). Implementasi Program Jalin Matra dalam Menanggulangi Kerentanan Kemiskinan di Pedesaan (Studi di Desa Ngroto Kecamatan Pujon Kabupaten Malang).

Martono, N. (2014). Sosiologi Perubahan Sosial: Prespektif Klasik, Posmodern, dan Poskolonial. Jakarta: Rajawali Pers.

Maryuarni. (2008). Pembangunan BUMDes dan Pemberdayaan Pemerintah Desa. Bandung: CV.Pustaka Setia.

Miles, \& Huberman, \&. (2014). Analisis Data Kualitatif. Terjemahan Tejetped Rohendi Rohidi. Jakarta: Universitas Indonesia.

Nur, H. R. (2017). Partisipasi Masyarkat Terhadap Badan Usaha Milik Desa (BUMDes) Sebagai Upaya Peningkatan Pendapatan Masyarakat Desa Pandansari Kecamatan Ngantang Kabupaten Malang.

Putra, A. S. (2015). Badan Usaha Milik Desa : Spirit Usaha Kolektif Desa. . Jakarta: Kementrian Desa, Pembangunan Daerah Tertinggal, dan Transmigrasi Republik Indonesia.

Tama, Y., \& Ovi, D. (2017). Dampak Badan Usaha Milik Desa bagi Kesejahteraan Masyarakat di Desa Karangrejek Kecamatan Wonosari Kabupaten Gunung Kidul.

Wirawan. (2015). Teori-Teori Sosial Dalam Tiga Paradigma (Fakta Sosial, Definisi, Dan Prilaku Sosial) Edisi Ke 4. . Jakarta: Prenada Media Group. 